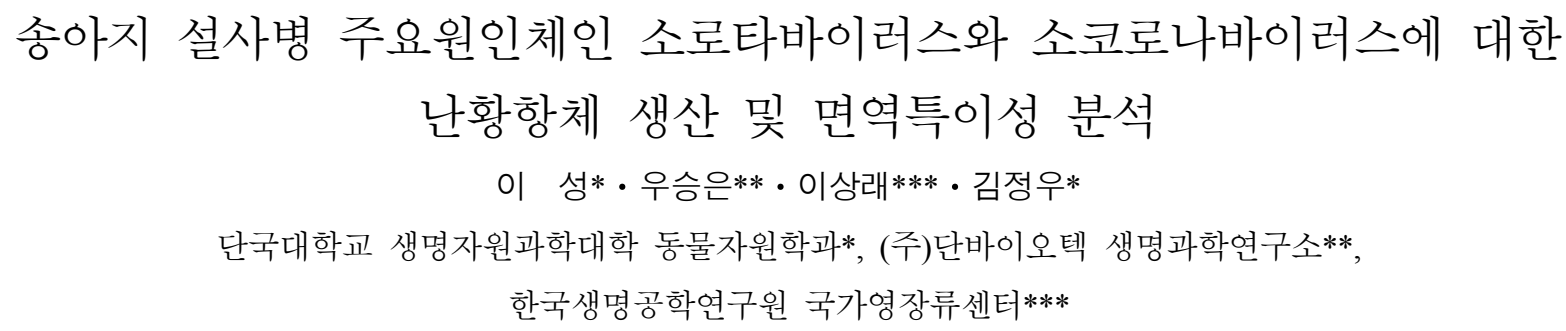

\title{
Immuno-specificity of Egg Yolk Antibodies against Bovine Rotavirus and Bovine Coronavirus causing Calf Diarrhea
}

\author{
Seong Lee*, Seung Eun Woo**, Sang Rae Lee*** and Jung Woo Kim* \\ Department of Animal Resources and Science, Dankook University*, Institute of Life Science, Danbiotech Ltd.**, \\ National Primate Research Center, Korea Research Institute of Bioscience and Biotechnology***
}

\begin{abstract}
This study was performed to produce specific egg yolk antibodies against bovine rotavirus (BRV) and bovine coronavirus (BCV) that are major pathogens causing diarrhea in calves. Chickens were immunized with BRV and BCV intramuscularly in the breast muscle by injection 5 times at two weeks interval. At 6 weeks after the first immunization of BRV or BCV, cross reactivity of each serum derived from BRV- or BCV-immunized hens was tested. Each serum antibody against BRV or BCV was reacted with only specific BRV or BCV antigens. Serum and egg yolk-antibody titers of hens against BRV or BCVwere highest at $8 \sim 12$ weeks after first immunization. Specific serum and egg yolk-antibody titers against BRV were about 104,000 and 107,000, respectively, and those against $\mathrm{BCV}$ were about 145,000 and 155,000, respectively. Hemagglutination inhibition titers in the immunized egg yolk antibodies against $\mathrm{BRV}$ and $\mathrm{BCV}$ were 5,120 and 1,280 , respectively, and were $\geq 8$ times higher than that in non-immunized control. These results suggested that the immunized egg yolk antibodies could effectively neutralize BRV and $\mathrm{BCV}$.
\end{abstract}

(Key words : Egg yolk antibody, BRV, BCV, Neutralization)

\section{I. 서 론}

소로타바이러스 (bovine rotavirus; BRV)는 어린 가축에서 위장염을 유발하는 주요 원인체로 전세계적으로 질병이 유발되고 있다. $\mathrm{BRV}$ 의 송아지 감염시 수양성 설사, 침울, 탈수 등의 증상이 나타나며 바이러스가 함유된 분변의 오 염물을 통하여 경구감염하는 것으로 알려져 있다 (Kuroki 등, 1994; Kuroki, 1999; Ciarlet 등, 2002; Yang 등, 2008).

소코로나바이러스 (bovine coronavirus; $\mathrm{BCV}$ ) 또한 가축에 서 위장염을 유발하는 주요 원인체의 하나로, 3 21일령의 어린 송아지 감염으로 많은 경제적 손실을 유발한 뿐만 아니라 성우에서도 Winter dysentery (WD)라고 하는 설사 병을 유발하여 전세계적으로 많은 나라에서 막대한 경제 적 피해를 유발하는 것으로 알려져 있다. 특히 낙농 성우
에서 폐사율은 1 2\%로 낮지만 전염율이 $50 \sim 100 \%$ 로 그 피해가 큰 것으로 알려져 있다(Ikemori 등, 1997; 안과 강, 1998; Kuroki 등, 1999; Kovacs-Nolan and Mine, 2004).

$\mathrm{BRV}$ 와 $\mathrm{BCV}$ 는 모두 주로 경구를 통하여 체내에 침입하 여 소화기 감염을 유발한다. 이러한 소화기 감염증 예방 을 위해서는, 여러 가지 방법들이 시도되어 왔는데, 대표 적으로 병원체에 대한 백신을 모체에 면역하여 초유내 항 체가를 높이는 방법이나 닭에 면역을 하여 얻어진 난황항 체를 초유와 혼합 또는 초유 대용으로 이용하는 방법 등 의 수동면역이 유효한 것으로 알려져 있고 이중에서도 특 히 난황항체의 방어 효과에 대하여 다수 보고가 되어 왔 다(Kuroki 등 1994; Ikemori 1997; Kuroki, 1999; BertolottiCiarlet 등, 2003; Kovacs-Nolan and Mine, 2004; Kim 등, 2008).

Corresponding author: Professor Jung Woo Kim, Department of Animal Resources and Science, Dankook University, San 29, Anseo, Cheonan, Chungnam 330-714, Korea. Tel: +82-41-550-3651, Fax: +82-41-555-8652, E-mail: kijuw@dankook.ac.kr 
난황항체는 모체가 획득한 면역항체가 난황 중에 이행 한 것으로 조류를 비롯하여 양서류, 파충류 및 폐어에서 도 발견되었으며, 닭을 이용한 난황항체의 생산성이나 경 제성, 그리고 종간 특이성으로 인한 교차반응이 적은 잇 점들로 인하여 최근 항체 생산은 물론 가축에서 감염성 질병 예방 및 치료 등에 이용하려는 시도가 많이 되고 있 다 (우 등, 1998; 신 등, 2000; 이 등, 2004; Kovacs-Nolan and Mine, 2004). 더욱이 근래 가축의 질병 치료나 예방을 목적으로 사용되는 항생제의 오남용과 슈퍼박테리아 출현 등 항생제 내성균 문제가 부각되고 있는 상황에서 항생제 를 대체하여 치료 및 예방 효과를 발휘하는 난황항체의 이용 가능성이 부각되고 있다(이 등, 2004; Kovacs-Nolan and Mine, 2004; Lee 등, 2009; Li 등, 2009; Mathew 등, 2009).

따라서, 본 연구는 국내에서도 빈번하게 발생하고 있는 어린 송아지에서의 $\mathrm{BRV}$ 및 $\mathrm{BCV}$ 감염증에 대한 방어책 강구의 일환으로, $\mathrm{BRC}$ 와 $\mathrm{BCV}$ 에 대한 특이 난황항체를 생산하고 이들의 면역특이성을 분석하여 그 이용 가능성 을 알아보고자 실시하였다.

\section{ㅍ. 재료 및 방법}

\section{1. 바이러스}

$\mathrm{BRV}$ 및 $\mathrm{BCV}$ 는 국립수의과학검역원으로 분양을 받아 실험에 이용하였다. $\mathrm{BRV}$ 와 $\mathrm{BCV}$ 배양을 위하여 각각 MA104 세포주(Rhesus monkey kidney cell line)와 MadinDarby bovine kidney(MDBK) 세포주를 사용하여 Eagle's minimum essential medium(EMEM)에 10\% Fetal bovine serum (FBS)을 첨가하여 배양하였다. 바이러스를 감염시킨 후 2 3 일경에 세포변성이 확인되면 얼리고 녹이는 과정 을 3회 반복하여 바이러스를 유리시키고 원심분리를 통하 여 얻어진 상청액을 모아 바이러스 역가를 측정하여 면역 에 이용하였다(Khattar and Pandey, 1990; 안과 강, 1998).

\section{2. 시험동물 및 면역방법}

본 연구를 위하여 36주령 Hyline Brown 품종의 산란계 를 이용하였다. 외관상 건강한 개체를 1 차 선별하였고 2 차적으로 $\mathrm{BRV}$ 및 $\mathrm{BCV}$ 에 대한 혈청 항체가를 측정하여 항체 형성이 되지 않은 30수를 시험동물로 공시하였다. 시험구의 배치는 완전 임의로 15 마리씩 2 개 군으로 나누 어 $\mathrm{BRV}$ 와 $\mathrm{BCV}$ 면역을 실시하였다. 시험동물은 개별 케 이지에 한 수씩 사육하였으며, 시험 전 기간 동안 일일 16 시간 점등하였고, 온도는 $22 \pm 2{ }^{\circ} \mathrm{C}$ 로 유지하였고, 사료와 물은 자유섭식토록 하였다.
산란계에 면역은 다음과 같이 실시하였다. 각각 $1 \times 10^{8}$ $\mathrm{PFU} / \mathrm{ml}$ 의 $\mathrm{BRV}$ 및 $\mathrm{BCV}$ 를 $0.15 \mathrm{M}$ PBS에 유화시킨 $0.5 \mathrm{ml}$ 을 동량의 Freund's adjuvant와 혼합하여 충분히 교반한 다 음 면역원으로 사용하였으며, 이를 산란계의 흉근 4군데 에 각각 $0.25 \mathrm{ml}$ 씩 근육주사를 실시하였다. 이러한 면역을 2주 간격으로 5회 수행하였다 (김 등, 2000).

\section{3. 혈청 및 난황에서 항체의 분리}

혈청 항체가 측정을 위하여, 산란계의 날개정맥으로부 터 혈액 $2 \mathrm{ml}$ 을 채취하여 30 분간 정치하여 응고시킨 다음, $3,000 \mathrm{rpm}$ 으로 원심분리하고 상청의 혈청을 분리하였다. 분리된 혈청은 $-70^{\circ} \mathrm{C}$ 에 보관하였다가 교차반응 시험 및 항체가 측정을 위한 실험에 사용하였다. 매일 수거된 계 란으로부터 난황항체의 분리는 김 등 (2000)의 방법에 따 라 실시하였다. 채집한 난으로부터 난황만을 분리한 후 증류수 $(\mathrm{pH} 5.0)$ 로 10 배 희석하고 다시 희석액을 $\mathrm{pH} 5.0$ 로 적정한 후 $-20^{\circ} \mathrm{C}$ 에서 24 시간 동결하였다. 동결된 난황희 석액을 해동시킨 다음, $15^{\circ} \mathrm{C}, 10,000 \mathrm{~g}$ 로 30 분간 원심분리 를 실시하여 상청액을 수거하였고, 다시 수거액을 $8^{\circ} \mathrm{C}$ 에 서 Whatman No. 1으로 여과하여 수용성 난황항체를 분리 하여 항체가 측정 및 혈구응집억제반응 시험에 사용하였 다.

\section{4. 혈청 항체의 교차반응 시험}

$\mathrm{BRV}$ 와 $\mathrm{BCV}$ antigen을 산란계에 2주 간격으로 5 번 면역 을 실시하는 동안, 실험 6주째에 혈청 중 항체형성 유무 를 확인하고 이들 항체의 각 항원에 대한 면역 특이성 검 사를 실시하였다. 송아지에서 설사병을 유발한다고 알려 져 있는 일부 대장균종 $(\mathrm{F} 4, \mathrm{~F} 5, \mathrm{~F} 6, \mathrm{~F} 41)$ 과 살모넬라균종 (S. typhimurium, S. dublin), 그리고 각각 $\mathrm{BRV}$ 및 $\mathrm{BCV}$ 항 원과의 교차반응 유무를 확인하기 위하여 indirect enzymelinked immunosorbent assay (ELISA)법으로 시험을 실시하였 는데, 그 측정방법은 다음과 같다 (김 등, 2000). Carbonatebicarbonate buffer $(\mathrm{pH}$ 9.6)에 각각의 항원을 혼합한 다음, MicrotestIII flexible Assay plate(Falcon, USA)에 $100 \mu \ell$ 씩 분주하여 $4^{\circ} \mathrm{C}$ 에서 하룻밤 동안 정치하였다. 항원이 피복 된 plate를 PBS-T $\left(0.02 \mathrm{M} \mathrm{NaH}_{2} \mathrm{PO}_{4}, 0.13 \mathrm{M} \mathrm{NaCl}, 0.05 \%\right.$ Tween 20, pH 7.2)로 3회 세척하였으며, blocking buffer (5 $\%$ skim milk, $\mathrm{pH} 7.3$, Difco)를 $175 \mu$ 씩 분주하여 2시간 동안 $25^{\circ} \mathrm{C}$ 에서 정치시켰다. Blocking buffer와 PBS-T를 동 량으로 섞은 희석용액을 이용하여 측정에 이용될 면역한 산란계의 혈청을 각각 3 배수씩 단계 희석하였으며 이를 각 well에 $100 \mu$ 씩 분주한 후 $37^{\circ} \mathrm{C}$ 에서 1 시간 30 분간 반 응시켰다. 2차 항체로는 alkaline phosphatase가 conjugation 
되어있는 AffiniPure rabbit $\mathrm{IgG}$ anti-chicken $\operatorname{IgY(Jackson,~}$ USA)를 5,000 배로 희석하여 사용하였으며, 이를 각 well에 $100 \mu \mathrm{l}$ 씩 분주 후 $37^{\circ} \mathrm{C}$ 에서 1 시간 30 분 동안 반응시켰다. 이후 phosphate substrate tablets ( $\mathrm{\rho}$-nitrophenyl phosphate) (Sigma, USA)를 $0.5 \mathrm{mM} \mathrm{MgCl}$ 가 함유된 $10 \%$ diethanolamine (pH 9.8) 용액에 용해시킨 기질을 plate에 가하여 $37^{\circ} \mathrm{C}$ 에서 20 분간 발색반응을 시켰다. $5 \mathrm{M} \mathrm{NaOH}$ 를 첨가하 여 반응을 정지시킨 후, Microplate reader (Molecular Devices; E Max)를 사용하여 $405 \mathrm{~nm}$ 에서 흡광도 (optical density)를 측정하였다. 이 결과를 이용하여 항체가를 산출 하였으며 모든 실험은 3 반복 실시하였다.

\section{5. 혈청 및 난황내 항체역가 측정}

$\mathrm{BRV}$ 및 $\mathrm{BCV}$ 에 대한 혈청 및 난황내 항체가 측정은 실 험 $0,2,4,6,8,12$ 주차에 ELISA법으로 실시하였으며, 앞서 서술한 교차반응 시험과 동일한 수순으로 진행하였 다 (김 등, 2000). 항원으로 각각 $1 \times 10^{8} \mathrm{PFU} / \mathrm{ml}$ 의 $\mathrm{BRV}$ 및 $\mathrm{BCV}$ 배양액을 사용하였으며, 면역한 산란계의 혈청 및 난황항체를 각각 3 배수씩 단계 희석하여 실험에 사용하였 으며 모든 실험은 3 반복 실시하였다.

\section{6. 혈구응집억제반응 (Hemagglutination inhibition test)}

혈구응집반응 (Hemagglutination; HA) 및 혈구응집억제반 응 (Hemagglutination inhibition; HI) 시험은 Park 등 (2007)의 방법을 변형하여 실시하였다. $\mathrm{HA}$ 시험은 $\mathrm{BRV}$ 및 $\mathrm{BCV}$ 각각의 배양액을 96-well V bottom plate (Falcon)에서 PBS 로 2 배수씩 단계 희석을 한 다음, $\mathrm{VAD}$ buffer $(0.15 \mathrm{M}$ $\mathrm{NaCl}, 0.3 \mathrm{M} \mathrm{Na} \mathrm{HPO}_{4}, 0.15 \mathrm{M} \mathrm{NaH}_{2} \mathrm{PO}_{4}, \mathrm{pH} 6.0$ )에 $0.5 \%$ 로 희석한 돼지 적혈구 용액을 동일부피로 첨가하여 혼합하 고 $4{ }^{\circ} \mathrm{C}$ 에서 정치하여 혈구응집반응을 유도하였다. $\mathrm{HI}$ 시 험을 위하여, 우선 실험 12 주차에 획득한 난황항체 수용 액을 2 배수씩 단계 희석하여 $50 \mu$ 씩 분주한 다음, 동일 부피의 바이러스 배양액 $(4 \mathrm{HA}$ units/ $50 \mu)$ 을 첨가하여 혼 합하고 상온에서 1 시간 동안 정치하였다. 이후, 동일 부피 의 $0.5 \%$ 돼지 적혈구 희석액을 가한 다음, $4{ }^{\circ} \mathrm{C}$ 에서 12 시 간 응집억제반응을 유도하였다. 모든 시험은 독립실험으 로 2반복 실시하였다.

\section{III. 결 과}

\section{1. $\mathrm{BRV}$ 와 $\mathrm{BCV}$ 를 면역한 산란계에서 혈청 항체의 면 역특이성}

$\mathrm{BRV}$ 와 $\mathrm{BCV}$ antigen을 산란계에 2 주 간격으로 5 번의 면
역을 실시하는 동안, 실험 6주째에 혈청 중 항체형성 유 무를 확인하고 이들 항체의 각 항원에 대한 면역 특이성 을 조사하기 위하여 일부 대장균종 (F4, F5, F6, F41)과 살 모넬라균종 (S. typhimurium, S. dublin), 그리고 각각 BRV 및 $\mathrm{BCV}$ 항원과의 교차반응 시험을 실시하였다. 그 결과, $\mathrm{BRV}$ 및 $\mathrm{BCV}$ 를 면역한 혈청은 각각 $\mathrm{BRV}$ 항원과 $\mathrm{BCV}$ 항 원과 특이적인 결합반응 보였으며, 시험에 사용한 대장균 종과 살모넬라균 종과는 전혀 반응하지 않는 것으로 나타 났다 (Table 1).

Table 1. Cross reactivity test of serum antibodies against BRV and BCV in laying hens

\begin{tabular}{llcc}
\hline \multirow{2}{*}{ Antigens } & & \multicolumn{2}{c}{ Serum antibodies* } \\
\cline { 3 - 4 } & & Anti-BRV & Anti-BCV \\
\hline \hline E. coli & F4 (K88) & - & - \\
E. coli & F5 (K99) & - & - \\
E. coli & F6 (987P) & - & - \\
E. coli & F41 & - & - \\
Salmonella & typhimurium & - & - \\
Salmonella & dublin & - & - \\
BRV & & ++ & - \\
BCV & & - & ++ \\
\hline
\end{tabular}

* Range of titer, +++: > 100,000; ++: > 50,000<100,000; +: < 50,$000 ;-:<1,000$

2. 산란계 혈청과 난황내 $\mathrm{BRV}$ 와 $\mathrm{BCV}$ 에 대한 항체 역 가의 변화

$\mathrm{BRV}$ 와 $\mathrm{BCV}$ antigen을 산란계에 2주 간격으로 5 회 면역 한 다음, 실험 $0,2,4,6,8,12$ 주에 각각의 항원에 대한 혈청 및 난황내 항체 역가를 측정하였다. 그 결과, $\mathrm{BRV}$ 및 $\mathrm{BCV}$ 에 대한 혈청 및 난황내 항체역가는 면역한 후 2 주 경부터 증가되기 시작하여 8 12주경에는 최고의 수준 에 도달하였다(Fig. 1). BRV에 대한 항체의 경우, 혈청과 난황내에서 면역 후 12 주째에 각각 약 104,000 과 107,000 의 역가 수준을 보였으며 (Fig. $1 \mathrm{~A}$ ), $\mathrm{BCV}$ 의 경우, 8 주째에 각각 약 145,000 과 155,000 의 수준을 보였다 (Fig. 1B). 그 리고, $\mathrm{BRV}$ 와 $\mathrm{BCV}$ 를 면역한 산란계 모두에서 $\mathrm{BRV}$ 및 $\mathrm{BCV}$ 항원 면역 첫 접종부터 4주경까지는 혈청항체 역가 의 수준이 난황항체 역가의 수준보다 높았으나 8 주 이후 부터는 난황항체의 역가 수준이 더 높은 것으로 나타났다 (Fig. 1).

\section{2. $\mathrm{BRV}$ 및 $\mathrm{BCV}$ 에 대한 난황항체의 특이 중화반응}

$\mathrm{BRV}$ 및 $\mathrm{BCV}$ 를 면역한 산란계로부터 획득한 난황항체 가 각 바이러스 항원을 중화할 수 있는 능력 유무를 확인 
A) Antibody titers against BRV

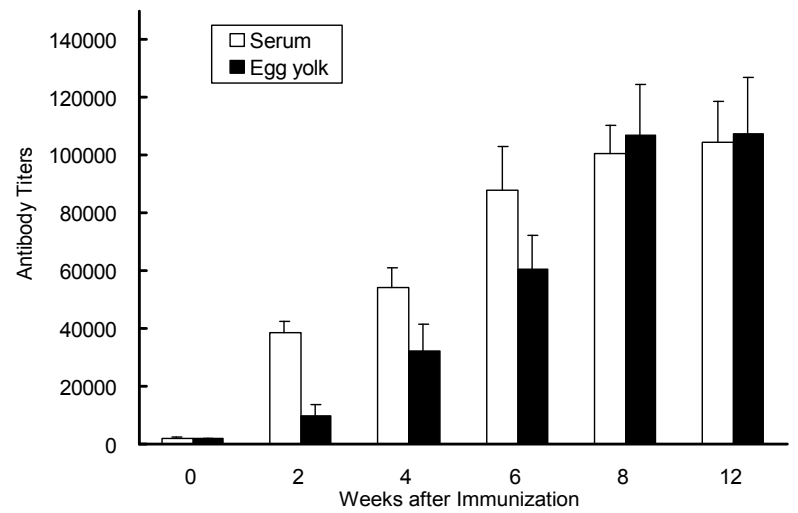

B) Antibody titers against BCV

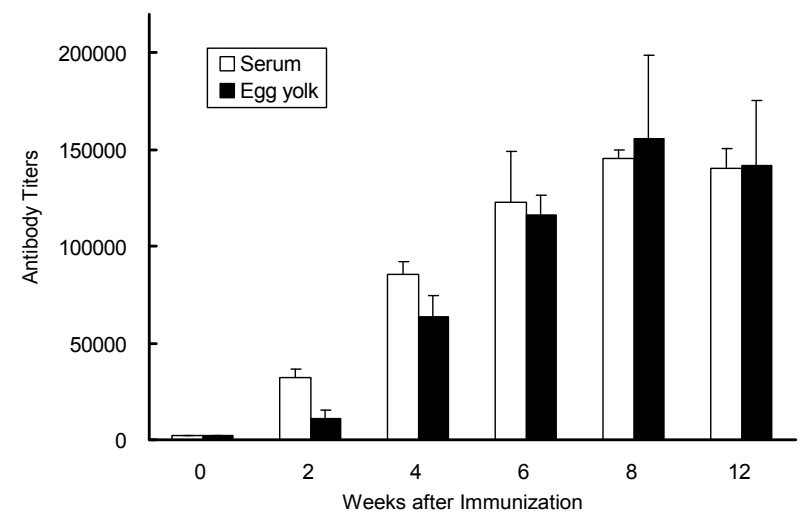

Fig. 1. Developmental changes of serum- and egg yolk-antibody titers of hens immunized with different viral antigens.

Serum; serum antibody titer, Egg yolk; egg yolk antibody titer.

하기 위하여 혈구응집억제반응시험 (HI test)을 실시하였다. 그 결과, $\mathrm{BRV}$ 항원을 면역한 산란계로부터 얻어진 난황 항체의 HI unit는 5,120로 비면역 대조군의 난황항체 역가 160 에 비해 월등히 높은 것으로 나타났으며 (Table 2), $\mathrm{BCV}$ 항원을 면역한 산란계의 난황항체도 역시 $\mathrm{HI}$ unit가 1,280 으로 대조군에 비하여 높은 중화력을 나타내는 것으 로 조사되었다 (Table 3).

Table 2. Hemagglutination inhibition activity of egg yolkantibodies of hens immunized with BRV

\begin{tabular}{lc}
\hline Group & HI titers of \\
\hline \hline Non-immunized hens & 160 \\
BRV-immunized hens & 5,120 \\
\hline
\end{tabular}

* Water soluble fraction(WSF) obtained from egg yolk at 12 weeks after the first immunization.

Table 3. Hemagglutination inhibition activity of egg yolkantibodies of hens immunized with BCV

\begin{tabular}{lc}
\hline Group & HI titers of WSF* against BCV \\
\hline \hline Non-immunized hens & 160 \\
BRV-immunized hens & 1,280 \\
\hline
\end{tabular}

* Water soluble fraction(WSF) obtained from egg yolk at 12 weeks after the first immunization.

\section{IV. 고 찰}

난황항체는 다클론성 항체이나 종특이적인 면역체계로 인하여 교차반응이 적은 항체 생산이 가능한 것으로 알려 져 있다(Knecht 등, 1996; Kovacs-Nolan and Mine, 2004). 본 연구에서도 $\mathrm{BRV}$ 와 $\mathrm{BCV}$ 항원을 면역한 산란계의 혈청
을 이용하여 가축에서 질병을 유발하는 일부 대장균종 (F4, F5, F6, F41)과 살모넬라균종 $(S$. typhimurium, $S$. dublin), 그리고 각각 $\mathrm{BRV}$ 및 $\mathrm{BCV}$ 항원과의 교차반응 시 험을 실시한 결과, $\mathrm{BRV}$ 및 $\mathrm{BCV}$ 를 면역한 혈청은 각각 $\mathrm{BRV}$ 및 $\mathrm{BCV}$ 항원과만 특이적인 결합반응 보였다. 이러 한 결과는, $\mathrm{BRV}$ 와 $\mathrm{BCV}$ antigen을 면역한 산란계로부터 $\mathrm{BRV}$ 및 $\mathrm{BCV}$ 특이적인 항체 생산이 가능하며, 이 난황항 체를 이용하여 수동면역 유도 시, 특이적인 항원항체 결 합반응이 유발될 가능성이 큰 것으로 사료되었다. 또한 혈구응집억제반응 시험에서 $\mathrm{BRV}$ 및 $\mathrm{BCV}$ 항원을 면역하 여 획득한 난황항체의 중화능력이 면역하지 않은 대조군 에 비하여 8 배 이상으로 월등히 높은 것을 확인할 수 있 었다. 이를 통하여, 면역에 의하여 획득된 난황항체가 실 질적으로 바이러스를 중화할 수 있는 활성이 있다는 것을 재확인하였다. 따라서, 본 연구에서 생산된 $\mathrm{BRV}, \mathrm{BCV}$ 에 대한 특이 난황항체를 현장에 적용할 경우, $\mathrm{BRV}$ 및 $\mathrm{BCV}$ 의 증식을 효과적으로 억제시킬 수 있을 것으로 사료된다.

산란계에서 각각의 항원을 접종한 후 주별 난황항체가 의 변화수준은 혈청항체가의 변화와 비슷한 양상을 보였 으나 그 변화 양상이 혈청항체가 보다 2주 정도 뒤에 나 타났다. 이러한 결과는 이미 보고된 바와 같은 결과와 동 일한 현상으로, 혈중에 존재하는 항체가 난황으로 이전되 는데 1 2주 정도가 소요되는 데서 기인된 것으로 판단된 다(Brown 등, 1989; Silim and Venne, 1989; Svendsen 등, 1996; 우 등, 1998; 신 등, 2000)

전세계적으로 $\mathrm{BRV}$ 와 $\mathrm{BCV}$ 는 송아지 설사병의 주요원인 에 포함되며, 국내에서도 실제로 신생송아지 설사분변에 서 분리가 되고 있다(Ikemori 등, 1997; 안과 강, 1998; Kuroki, 1999; Yang 등, 2008). 이러한 BRV 및 BCV 감염 증을 예방하기 위하여 여러 가지 노력들이 진행되고 있는 
데, 대표적인 것이 난황항체를 이용한 수동면역이며 그 유용성이 보고되어 왔다 (Kuroki 등, 1994; Ikemori 등, 1997; Kuroki, 1999; Kovacs-Nolan 등, 2001). 따라서, 국내 에서도 이와 같은 시도를 할 필요성이 있으며, 더불어 난 황항체의 이용을 확대할 필요성이 있다. 결론적으로 본 실험을 통하여, 송아지 설사병의 주요 원인체인 $\mathrm{BRV}$ 및 $\mathrm{BCV}$ 에 대한 특이적인 난황항체를 생산하여 in vitro에서 그 중화 활성을 확인하였으며, 이러한 특이 난황항체를 실제 임상에 적용하기 위해서는 송아지 적용 시험이 추가 적으로 이루어져야 할 것이다.

\section{V. 요 약}

본 연구는 송아지 설사병의 주요원인체 중 소로타바이 러스(bovine rotavirus; BRV)와 소코로나바이러스(bovine coronavirus; $\mathrm{BCV}$ )에 대한 난황항체를 생산하고 이의 면역 특이성을 확인하고자 실험을 실시하였으며, $\mathrm{BRV}$ 및 $\mathrm{BCV}$ 를 2주 간격으로 5 회 산란계에 근육주사를 실시하여 혈청 과 난황내의 특이 항체 형성 유무를 확인하였다. 실험 6 주차에 면역한 산란계로부터 획득한 혈청을 이용하여 교 차반응 시험을 실시한 결과, $\mathrm{BRV}$ 및 $\mathrm{BCV}$ 를 면역하여 얻 은 혈청은 각각 $\mathrm{BRV}$ 및 $\mathrm{BCV}$ 항원과만 특이적인 결합반 응을 보였다. 면역에 따른 혈청항체 및 난황항체의 수준 은 실험 8 12주차에 최고도에 달했고, $\mathrm{BRV}$ 에 대한 항체 의 경우 혈청과 난황내에서 면역 후 12 주째에 각각 약 104,000 과 107,000 의 역가 수준을 보였으며, $\mathrm{BCV}$ 의 경우 8 주째에 각각 약 145,000 과 155,000 의 수준을 보였다. $\mathrm{BRV}$ 및 $\mathrm{BCV}$ 에 대한 중화능력 유무 확인을 위하여 분리 된 난황항체를 이용하여 혈구응집억제반응 시험을 실시한 결과, $\mathrm{BRV}$ 및 $\mathrm{BCV}$ 에 대한 혈구응집억제 희석비가 각각 5,120 및 1,260 으로 면역하지 않은 대조군에 비하여 8 배 이상 높은 중화력을 나타냈다. 이러한 결과를 종합하면, 산란계에 $\mathrm{BRV}$ 및 $\mathrm{BCV}$ 를 면역하여 얻어진 난황항체는 $\mathrm{BRV}$ 및 $\mathrm{BCV}$ 에 대한 면역 특이성을 가지고 중화할 수 있 는 능력이 있으며, 이러한 난황항체는 $\mathrm{BRV}$ 및 $\mathrm{BCV}$ 의 증 식을 효과적으로 억제시킬 수 있어 임상에 적용할 경우 유용할 것으로 사료된다.

\section{VI. 사 사}

이 연구는 2007년도 농촌진흥청 농업특정연구사업의 지 원 (과제번호: 20070101033075)으로 이루어졌으며 이에 깊 이 감사를 드립니다.

\section{VII. 인 용 문 헌}

1. 김정우, 김도균, 김 철. 2000 . 장관독성 대장균 $\mathrm{K} 99(\mathrm{~F} 5)$ 의 섬모항원에 대한 특이 난황항체의 생산. 한국동물자원학과학 회지. 42:371-378.

2. 신나리, 김종만, 유한상. 2000. 난황항체를 이용한 돼지 호흡 기 질병 방제에 관한 연구 1 . bordetella bronchiseptica, pasteurella multocida 및 actinobacillus pleuropneumoniae의 주 요 면역원 분석 및 $\mathrm{IgY}$ 의 생산. 대한수의학회지. 40(3):551561.

3. 안재문, 강신영. 1998. 소 코로나바이러스에 대한 단클론항체 생산과 특성. 대한수의학회지. 38(3):581-588.

4. 우승룡, 김종만, 권창희, 이희수, 임숙경, 김종염. 1998. 난황 항체를 이용한 돼지 대장균 설사증 방제기법 개발 1 . 대장균 pilus 항원과 LT로 면역시킨 닭의 면역반응. 대한수의학회지. 38(4):829-836.

5. 이희수, 김종만, 우승룡, 정병열, 조윤상, 유한상, 윤용덕, 허 원, 문영식, 오진식. 2004. 난황면역제를 이용한 개 주요 소 화기 및 호흡기질병의 방제에 관한 연구 II. 난황면역제의 실 험동물과 개에 있어서의 질병방제 효과. 대한수의학회지. 44(3):415-420.

6. Bertolotti-Ciarlet, A., Ciarlet, M., Crawford, S. E., Conner, M. E. and Estes, M. K. 2003. Immunogenicity and protective efficacy of rotavirus 2/6-virus-like particles produced by a dual baculovirus expression vector and administered intramuscularly, intranasally, or orally to mice. Vaccine. 21:38853900.

7. Brown, J., Resurreccion, R. S., Dickson, T. G. and Horne, A. 1989. The relationship of egg yolk and serum antibody. I. Infectious bursal disease virus. Avian Dis. 33(4):654-656.

8. Ciarlet, M., Hyser, J. M. and Estes, M. K. 2002. Sequence analysis of the VP4, VP6, VP7, and NSP4 gene products of the bovine rotavirus WC3. Virus Genes. 24:107-118.

9. Ikemori, Y., Ohta, M., Umeda, K., Icatlo, F. C., Kurok, M., Yokoyama, H. and Kodama, Y. 1997. Passive protection of neonatal calves against bovine coronavirus-induced diarrhea by administration of egg yolk or colostrum antibody powder. Vet. Microbiol. 58(2-4):105-111.

10. Khattar, S. and Pandey, R. 1990. Cell culture propagation of calf rotavirus and detection of rotavirus specific antibody in colostrum and milk of cows and buffaloes. Rev. Sci. Tech. 9(4):1131-1138.

11. Kim, D. S., Lee, T. J., Kang, J. H., Kim, J. H., Lee, J. H., Ma, S. H., Kim, S. Y., Kim, H. M. and Shin, S. M. 2008. Immunogenicity and safety of a pentavalent human-bovine (WC3) reassortant rotavirus vaccine in healthy infants in 
Korea. Pediatr. Infect. Dis. J. 27:177-178.

12. Knecht, W., Kohler, R., Minet, M. and Loffler, M. 1996. Antipeptide immunoglobulins from rabbit and chicken eggs recognize recombinant human dihydroorotate dehydrogenase and a $44-\mathrm{kDa}$ protein from rat liver mitochondria. Eur. J. Biochem. 236:609-613.

13. Kovacs-Nolan, J. and Mine, Y. 2004. Passive Immunization Through Avian Egg Antibodies. Food Biotechnology. 18(1):3962.

14. Kuroki, M. 1999. Oral passive immunization using chicken egg yolk immunoglobulins against bovine rotavirus and coronavirus infections. Recent research developments in virology. 1(1):95106.

15. Kuroki, M., Ohta, Y., Ikemori, Y., Peralta, R. C., Yokoyama, H. and Kodama, Y. 1994. Passive protection against bovine rotavirus in calves by specific immunoglobulins from chicken egg yolk. Arch. Virol. 138:143-148.

16. Lee, S. H., Lillehoj, H. S., Park, D. W., Jang, S. I., Morales, A., García, D., Lucio, E., Larios, R., Victoria, G., Marrufo, D. and Lillehoj, E. P. 2009. Protective effect of hyperimmune egg yolk IgY antibodies against Eimeria tenella and Eimeria maxima infections. Vet. Parasitol. 163(1-2):123-126.

17. Li, X. Y., Jin, L. J., Uzonna, J. E., Li, S. Y., Liu, J. J., Li, H. Q., Lu, Y. N., Zhen, Y. H. and Xu, Y. P. 2009. Chitosan-alginate microcapsules for oral delivery of egg yolk immunoglobulin (IgY): in vivo evaluation in a pig model of enteric colibacillosis. Vet. Immunol. Immunopathol. 129(1-2):
132-136.

18. Mathew, A. G., Rattanatabtimtong, S., Nyachoti, C. M. and Fang, L. 2009. Effects of in-feed egg yolk antibodies on Salmonella shedding, bacterial antibiotic resistance, and health of pigs. J. Food Prot. 72(2):267-273.

19. Park, J. S., Choi, B. K., Vijayachandran, L. S., Ayyappan, V., Chong, C. K., Lee, K. S., Kim, S. C. and Choi, C. W. 2007. Immunodetection of Canine Parvovirus (CPV) in clinical samples by polyclonal antisera against CPV-VP2 protein expressed in Esherichia coli as an antigen. J. Virol. Methods. 146(1-2):281-287.

20. Silim, A. and Venne, D. 1989. Comparison of egg-yolk and serum antibody titers to four avian viruses by enzyme-linked immunosorbent assay using paired field samples. Avian Dis. 33(4):643-648.

21. Svendsen, B. L., Crowley, A., Stodulski, G. and Hau, J. 1996. Antibody production in rabbits and chickens immunized with human IgG. A comparison of titre and avidity development in rabbit serum, chicken serum and egg yolk using three different adjuvants. J. Immunol. Methods. 191(2):113 120.

22. Yang, D. K., Kim, B. H., Lee, K. W., Kim, Y. H., Song, J. Y., Park, J. W. and Son, S. W. 2008. Genetic characterization of bovine rotavirus isolates in Korea. Korean J. Vet. Res. 48(4):423-429.

(접수일자 : 2009. 8. 19. / 수정일자 : 2009. 10. 15. /

채택일자 : 2009. 10. 16.) 